\title{
SURVIVAL OF TRANSLOCATED GREATER SAGE-GROUSE HENS IN NORTHEASTERN CALIFORNIA
}

\author{
Chad B. Bell ${ }^{1}$ and T. Luke George ${ }^{2}$
}

\begin{abstract}
Translocation success of Greater Sage-Grouse (Centrocercus urophasianus) is generally measured by documenting whether translocated individuals survive and reproduce at the release site. However, demographic parameters, such as annual survival of translocated individuals, provide a more accurate measure of translocation success. We translocated 60 female sage-grouse from Oregon and Nevada to Clear Lake National Wildlife Refuge, California, during 2005-2010 to augment a small population of resident grouse. We radio-marked each translocated female and a sample of resident female sage-grouse, recorded their locations, and monitored their survival at monthly intervals over the study period. We observed most (55/60) translocated birds near $(<100 \mathrm{~m}$ from) the only lek in the study area within one week of their release. To examine factors influencing survival, we developed a set of a priori models that included the effects of translocation status, season (breeding vs. nonbreeding), year, and age on annual survival and compared the models' $\mathrm{AIC}_{c}$ values using program MARK. The null model was the best supported model and received $33 \%$ of the model weight. Models that included survival during the first year posttranslocation, age, and season, however, were competitive $(<2$ $\Delta \mathrm{AIC}_{c}$ ) with the top model. However, the $\beta$ coefficient distinguishing breeding from nonbreeding season survival was the only coefficient whose $95 \%$ confidence interval did not overlap zero; monthly survival during the breeding season $(0.952$ $\pm 0.014)$ was lower than during the nonbreeding season $(0.960 \pm 0.008)$. The model average estimate of annual survival for female sage-grouse in our study area was $59.6 \%$ (95\% CI 47.9-70.1). Our analyses provide little support for a difference in survival between translocated and resident sage-grouse, and our annual survival estimates were comparable to annual survival estimates of resident sage-grouse in other locations. Our results suggest that when current recommendations for translocation protocols are followed, translocated female sage-grouse survive just as well as resident individuals and quickly integrate into the local population.
\end{abstract}

RESUMEN.-El éxito del traslado del urogallo de las praderas (Centrocercus urophasianus) generalmente se ha medido al documentar si los ejemplares trasladados han sobrevivido y se han reproducido en los lugares donde han sido puestos en libertad. Sin embargo, los parámetros demográficos como la tasa anual de supervivencia de ejemplares trasladados proveen una medida más precisa del éxito del traslado. Trasladamos a 60 urogallos hembras de Oregón y Nevada al Clear Lake National Wildlife Refuge (Refugio Nacional para la Fauna Silvestre Clear Lake) en California entre 2005 y 2010 con el fin de incrementar la población pequeña de urogallos residentes. Se colocó un trasmisor telemétrico a cada ejemplar trasladado y a una muestra de hembras residentes y registramos sus ubicaciones y monitoreamos su supervivencia en intervalos de un mes durante dicho periodo. Observamos a la mayoría (55/60) de las aves trasladadas cerca (a menos de $100 \mathrm{~m}$ ) del único grupo de machos en el área de estudio durante la primera semana de haber sido puestas en libertad. Para poder examinar los factores que afectaron la supervivencia, desarrollamos un conjunto de modelos a priori en los que se incluyeron los efectos del estado de traslado, la estación, el año y la edad sobre la supervivencia anual y comparamos sus valores de $\mathrm{AIC}_{c}$ usando el programa MARK. El modelo nulo fue el modelo más apoyado y recibió el 33\% de peso relativo. Sin embargo, los modelos que incluyeron supervivencia durante el primer año después del traslado, la edad y la temporada de apareamiento fueron competitivos $\left(<2 \Delta \mathrm{AIC}_{c}\right)$ en relación con el modelo más apoyado. No obstante, el coeficiente beta que distingue la supervivencia durante la temporada de apareamiento de la supervivencia durante el resto del año fue el único coeficiente cuyo intervalo de confianza de $95 \%$ no incluyó al cero; la supervivencia mensual durante la temporada de apareamiento $(0.952 \pm 0.014)$ fue menor que la supervivencia fuera de dicha temporada $(0.960 \pm 0.008)$. El promedio ponderado de la supervivencia anual de los urogallos hembras en nuestra área de estudio fue 59.6\% (IC 95\% 47.9-70.1). Nuestro análisis brinda poco respaldo en cuanto a la diferencia de supervivencia entre los urogallos trasladados y los residentes, y nuestras estimaciones de la supervivencia de urogallos fueron comparables a las estimaciones de supervivencia de individuos residentes en otras áreas. Nuestros resultados sugieren que cuando se cumplen las recomendaciones actuales para los protocolos de traslado, los urogallos hembras trasladados sobreviven tanto como los ejemplares residentes y se integran rápidamente a la población local.

Greater Sage-Grouse (Centrocercus urophasianus) populations have been declining throughout their range since the early 1900s, with substantial declines on the periphery of their range (Schroeder et al. 2004). These declines have raised concerns about the long-term

\footnotetext{
${ }^{1}$ U.S. Fish and Wildlife Service, Klamath Basin National Wildlife Refuge Complex, 4009 Hill Road, Tulelake, CA 96134. E-mail: chad_bell@fws.gov ${ }^{2}$ Department of Wildlife, Humboldt State University, Arcata, CA 95521.
} 
persistence of Greater Sage-Grouse (hereafter, sage-grouse) across much of their range, leading to their designation as "warranted but precluded" under the Endangered Species Act (USFWS 2010). Translocations have been used as a management tool to restore or augment declining populations of sage-grouse for several decades. The use of translocation as a management approach for sage-grouse has been questioned, however, because translocation success as measured by persistence of reintroduced populations or increases of extant populations has been very low (Reese and Connelly 1997). Modifications of translocation methods may improve translocation success (Reese and Connelly 1997), but more precise measures of translocation success are needed to assess the efficacy of translocations as a management tool.

Game birds generally have low rates of annual survival and high reproductive rates; therefore, management programs have often focused on increasing nesting success and chick survival (Crawford et al. 2004, Clark et al. 2008, Devers et al. 2009). Recent analyses of sage-grouse demographics, however, suggest that female survival has a similar or greater influence on population growth rate than other demographic parameters (Johnson and Braun 1999, Dahlgren 2009, Taylor et al. 2012). Survival of translocated sage-grouse may be lower because of the stress associated with transport and the birds' lack of knowledge of the release site (Hagen 2011). If translocated birds have lower survival than resident birds, translocation may not be an effective means of augmenting small or declining populations. Though there have been numerous studies of survival of resident sage-grouse (Wallestad 1975, Zablan 1993, Moynahan et al. 2006), only 2 studies have examined annual survival of translocated sage-grouse (Musil et al. 1993, Baxter et al. 2008). In addition, there has been no published study comparing survival of resident and translocated sage-grouse at the same site, making it difficult to assess the efficacy of translocation as a management tool.

Although few data have been published on sage-grouse population trends in California, available data suggest sage-grouse have declined dramatically in some areas over the past 35 years (Hall 1995, Schroeder et al. 2004, Shuford, and Gardali 2008). Sage-grouse in northeastern California were extirpated from Siskiyou County around 1945, but they presently occupy Modoc and Lassen counties (Hall 1995, Schroeder et al. 1999). The sagegrouse population in western Modoc County has contracted from 46 active leks over an area of 460,000 ha in the 1960s to one active lek on Clear Lake National Wildlife Refuge (CLNWR). Between 1992 and 2005, the peak male lek count for the remaining lek on the CLNWR declined from 62 to 5 individuals (Horney 2010). Sage-grouse declines in northern California have been attributed to habitat loss and degradation associated with western juniper (Juniperus occidentalis Hook.) encroachment and invasions of exotic annual grasses such as cheatgrass (Bromus tectorum L.) and medusahead (Taeniatherum caput-medusae [L.] Nerski; Hall 1995, Horney 2010). The U.S. Fish and Wildlife Service started translocating sagegrouse to CLNWR in 2005 to augment the population.

To examine the efficacy of translocation as a management tool, we recorded the location of translocated birds after their release and estimated annual survival of resident and translocated sage-grouse at CLNWR from 2005 to 2011. In addition, we examined the effects of age, year, month, and season on grouse survival in our study area.

\section{Methods}

\section{Study Area}

We conducted the study in the area surrounding the only known sage-grouse lek on CLNWR, which is located in northeastern California. The land encompasses 103,000 ha, and ownership is divided among the Modoc National Forest, CLNWR, California State Lands, and a few private landowners. The study area consisted of wide valley floors that are interrupted by mountains with elevations between 1200 and $1900 \mathrm{~m}$ (Barbour et al. 2007). Mean monthly temperatures range from -6.6 to $29.3{ }^{\circ} \mathrm{C}$, with a short frost-free season, cold winters, and warm summers. Precipitation ranges from 50 to $62 \mathrm{~cm}$ annually (WRCC 2010). The vegetation is shrubsteppe habitat consisting primarily of low sagebrush (Artemisia arbuscula Nutt.) with fewer green rabbitbrush (Chrysothamnus viscidiflorus Hook.), bitterbrush (Purshia tridentata [Pursh] DC.), and big sagebrush (Artemisia tridentata Nutt.) along with isolated stands of western 
juniper (Juniperus occidentalis Hook.). The herbaceous layer is characterized by perennial bunchgrasses including bluebunch wheatgrass (Pseudoroegneria spicata [Pursh] Á. Löve) and Idaho fescue (Festuca idahoensis Elmer; Barbour et al. 2007).

Sage-grouse donor populations were chosen at Hart Mountain (Lake County, OR) and Wall Canyon (Washoe County, NV) from among other populations because of genetic similarities between the donor and recipient populations (Oyler-McCance et al. 2005) and habitat similar to the release site. Oregon capture sites consisted of sagebrush flats with rolling hills, elevations ranging from 1200 to $2450 \mathrm{~m}$ (Gregg et al. 1994), mean annual precipitation of 29 $\mathrm{cm}$, and mean monthly temperatures of -9.1 to $24{ }^{\circ} \mathrm{C}$. The vegetation is dominated by low sagebrush, big sagebrush, green rabbitbrush, and stands of western juniper (Gregg et al. 1994). Nevada capture sites, near Wall Canyon Reservoir, ranged from 1280 to $2530 \mathrm{~m}$ in elevation, and from 15.2 to $63.5 \mathrm{~cm}$ in annual precipitation. Vegetation at the Nevada sites consisted of big sagebrush, low sagebrush, and stands of western juniper (Evans 1986).

\section{Capture}

Sage-grouse hens were translocated from Oregon (2005, 2006, and 2009) and Nevada (2007, 2008, and 2010). Sage-grouse donor populations were selected from stable populations as determined by trend analysis of peak lek counts conducted by the Oregon Department of Fish and Wildlife and the Nevada Department of Wildlife in their respective states.

Translocated sage-grouse hens were captured in late March through early April at night for a period lasting 2-8 hours after sunset. Hens were located around known lek locations using a modified spotlighting technique (Giesen et al. 1982). After capture, each hen was placed into a $30 \times 20 \times 30$-cm cardboard box lined with wood chips. Captured sage-grouse were moved from the capture site to a processing area where the birds were weighed and assigned an age class by feather features (Crunden 1963). Each translocated hen was fitted with a $19-\mathrm{g}$ or $22-\mathrm{g}(<4 \%$ of body mass) necklace-style radio-transmitter (Advanced Telemetry Systems Inc., Isanti, $\mathrm{MN}$; 45 pulses per minute with mortality after 8 hours). Captured hens were transported to
CLNWR and released near the active lek within 2 hours of sunrise. The release area was chosen such that there was ample sagebrush density, both at the release site and between the release site and the lek, to provide hens with cover immediately after release and while moving toward the lek.

We captured resident sage-grouse hens in the study area at night after sunset during a period from late September to late October (2008-2010). These hens were located near known roost sites by using the same spotlighting technique as used for translocated hens. They were also fitted with radio-transmitter models as previously described. Resident hens were released after processing at the capture site.

\section{Monitoring}

We monitored radio-marked hens via telemetry using an R4000 receiver and 2-element Yagi antenna (Advanced Telemetry Systems Inc., Isanti, MN) for survival during 20052010. We located hens from the ground on a weekly basis from March through September. We located grouse using a fixed-winged aircraft when they could not be located from the ground. From October through February, hens were monitored by radiotelemetry from a fixedwinged aircraft scheduled every other week. The aerial searches were followed by ground searches of any radio-transmitters producing a mortality signal. All hens were monitored until death or transmitter failure (malfunction or battery depletion). All ground-monitored grouse locations were identified by walking a $10-15-\mathrm{m}$ radius around the bird and recording the location using a handheld global positioning system (GPS) receiver. Mortalities were assessed by searching for grouse remains and examining the carcass and surroundings for evidence as to the cause of death. All remains found from radio-marked grouse were sent to the National Wildlife Health Center-U.S. Geological Survey (Madison, WI) to determine cause of death, with particular focus on diseases.

\section{Data Analysis}

Telemetry and visual observations from year-round monitoring of translocated and resident hens were used in calculating survival. The fate of each radio-marked hen was assessed 2-6 times each month. These observations 
were used to produce monthly staggeredentry known-fate encounter histories (alive or dead) for known-fate models in Program MARK (White and Burnham 1999). A hen alive at the beginning of the month but found dead during subsequent observations during that month was considered a mortality. Transmitters that failed during the course of the study were censored in the analysis. The year (2005-2010) and the age class at the beginning of the year (adult or juvenile) were used as covariates in the analyses. In addition, grouse were divided into 3 groups: translocated, posttranslocated, and resident. Individuals were identified as translocated during the first 12 months after release (1 March-28 February); translocated birds that survived their first year after release were then identified as posttranslocated individuals. Resident birds were birds captured on the study site that had not been translocated (all translocated grouse had transmitters and therefore could be identified at capture). To examine seasonal effects, we used 3 biologically defined time periods that have been used in other studies of sagegrouse survival: nesting-early brood-rearing (1 Apr-30 Jun), late brood rearing-fall (1 Jul$30 \mathrm{Nov}$ ), and winter (1 Dec-31 Mar; Baxter et al. 2008).

We developed 13 a priori candidate models to examine the effects of time, age, and translocation status on annual survival. Survival over time was modeled as constant or as varying across seasons, by month, or by year. We also contrasted survival during the nesting and early brood-rearing season to the remaining months, because previous studies indicate that sage-grouse hens experience lower survival during this period (Schroeder et al. 1999, Baxter et al. 2008), and we felt this difference might be accentuated in translocated hens. Additional models included age and translocation status (translocated, posttranslocated, and resident). We also examined whether survival differed between hens in their first year after translocation and all other hens by including a model that combined posttranslocated and resident individuals (first-year survival). We considered models with additive interactions between age and year and between age and first-year survival. We used Akaike's information criterion for small sample sizes $\left(\mathrm{AIC}_{c}\right)$ to compare the models (Burnham and Anderson 2002). If there was no clear top model, we used model averaging to obtain survival estimates and $95 \%$ confidence intervals.

\section{RESUlTS}

We translocated 60 sage-grouse hens from Nevada and Oregon to CLNWR during 2005-2010 (one hen died during transport in 2009). We captured 20 resident sage-grouse during 2008-2010 within the study area. No females died during capture or were obviously injured during handling. All hens were released near the lek within $12 \mathrm{~h}$ of capture. All surviving sage-grouse hens were monitored for the entire period of the anticipated transmitter battery life, with the exception of 4 hens ( 2 in 2007, 1 in 2008, 1 in 2010), whose transmitters failed prematurely (2-6 months postrelease). Necropsies were performed on 3 hens whose mostly intact remains were recovered. The cause of death was predation in every case, and no diseases were detected, including West Nile virus.

The most parsimonious model was constant survival ( $\varphi=0.958,95 \%$ CI $0.941-0.970)$, and it received of $33 \%$ of the $\mathrm{AIC}_{c}$ weight (Table 1). The second-ranked model was $1.64 \mathrm{AIC}_{c}$ units below the top model and contrasted survival for first-year posttranslocated hens $(\varphi$ $=0.961,95 \%$ CI $0.940-0.976)$ and others $(\varphi=$ $0.953,95 \%$ CI $0.924-0.971$ ). The $95 \%$ confidence interval for the translocation $\beta$ coefficient estimate overlapped zero. The thirdranked model contrasted survival during the nesting and early brood-rearing period to the rest of the year, and the $\beta$ coefficient did not overlap zero. Monthly survival during the nesting and early brood-rearing period $(\varphi=$ 0.952 , 95\% CI $0.915-0.973$ ) was lower than during the rest of the year $(\varphi=0.960,95 \% \mathrm{CI}$ 0.941-0.973). The fourth-ranked model included age class. Annual survival rate for adults $(\varphi=0.957,95 \%$ CI $0.936-0.971)$ was lower than for juvenile hens $(\varphi=0.960,95 \%$ CI $0.928-0.979$ ), but the $95 \%$ confidence interval of the $\beta$ coefficient overlapped zero. $\mathrm{No}$ other models were within $2 \mathrm{AIC}_{c}$ of the top model. Because there was no clear top model, we used model averaging to obtain a survival estimate that included model selection uncertainty. Annual survival based on model averaging of monthly survival estimates across all candidate models was 0.596 (95\% CI 0.483-0.699). 
TABLE 1. A priori models used to examine the influence of year, season, age, and residency status on female sage-grouse survival at Clear Lake National Wildlife Refuge, California, during 2005-2010.

\begin{tabular}{|c|c|c|c|c|c|}
\hline Modela $^{\mathrm{a}}$ & $\mathrm{K}^{\mathrm{b}}$ & $\mathrm{AIC}_{c}{ }^{\mathrm{c}}$ & $\Delta \mathrm{AIC}_{c}{ }^{\mathrm{d}}$ & $\omega_{i}{ }^{\mathrm{e}}$ & Deviance \\
\hline$\{\mathrm{S}()\}$. & 1 & 283.733 & 0.000 & 0.327 & 281.728 \\
\hline$\{\mathrm{S}($ 1st yr trans. $)\}$ & 2 & 285.371 & 1.638 & 0.144 & 281.357 \\
\hline$\{\mathrm{S}(\mathrm{NS})\}$ & 2 & 285.483 & 1.750 & 0.136 & 281.468 \\
\hline$\{\mathrm{S}($ age $)\}$ & 2 & 285.675 & 1.942 & 0.124 & 280.660 \\
\hline$\{\mathrm{S}($ Trans. status $)\}$ & 3 & 286.635 & 2.901 & 0.076 & 280.605 \\
\hline$\{\mathrm{S}($ lst yr trans. $+\mathrm{NS})\}$ & 3 & 287.122 & 3.389 & 0.060 & 281.092 \\
\hline$\{\mathrm{S}($ lst yr trans. + age $)\}$ & 4 & 287.385 & 3.652 & 0.052 & 280.355 \\
\hline$\{\mathrm{S}($ seasons $)\}$ & 3 & 287.427 & 3.694 & 0.051 & 281.398 \\
\hline$\{\mathrm{S}($ year $)\}$ & 5 & 289.808 & 6.075 & 0.015 & 279.733 \\
\hline$\{\mathrm{S}($ year + age $)\}$ & 6 & 291.838 & 8.105 & 0.005 & 279.733 \\
\hline$\{\mathrm{S}($ month $)\}$ & 12 & 292.693 & 8.960 & 0.003 & 270.360 \\
\hline$\{\mathrm{S}($ Trans. status + year + age $)\}$ & 8 & 294.886 & 11.153 & 0.001 & 278.705 \\
\hline$\{\mathrm{S}($ 1st yr trans. * age $)\}$ & 11 & 299.372 & 15.639 & 0.000 & 277.039 \\
\hline
\end{tabular}

a Model notation as follows: (.) = constant survival across months and years; (seasons) = nesting - early brood rearing (1 Apr-30 Jun), late brood rearing - autumn $(1 \mathrm{Jul}-30 \mathrm{Nov})$, and winter $(1 \mathrm{Dec}-31 \mathrm{Mar}) ;(\mathrm{NS})=$ nesting - early brood rearing versus the rest of the year; $(\mathrm{t})=$ survival differed by year; $($ month $)=$ survival differed by month. Additional covariates included the following: (age) $=$ age of individual (juvenile or adult) at the start of the year; (Trans. status) $=$ translocation status (first year after translocation, post-first year after translocation, resident); (1st yr trans.) = translocated individuals during their first year after translocation versus others.

$\mathrm{b}_{\mathrm{K}}=$ number of parameters in the model

cAIC $_{c}=$ Akaike's information criterion adjusted for small sample size.

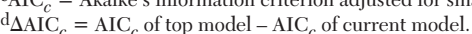

$\mathrm{e}_{\omega_{i}}=$ Akaike weight.

\section{Discussion}

Annual survival of female sage-grouse during their first year after translocation was similar to that of resident females, and their annual survival rate $(62.4 \%, 95 \%$ CI $48.2-74.8)$ was slightly higher than the mean survival estimates $(58 \%$, 95\% CI 54-61) for resident grouse throughout their range (Taylor et al. 2012). Sage-grouse survival has been examined in several populations across the species' range, but all of these studies focused on either resident grouse (Wallestad 1975, Connelly et al. 1994, Zablan et al. 2003, Moynahan et al. 2006) or translocated sage-grouse (Musil et al. 1993, Baxter et al. 2008). Ours is the first published study to examine annual survival of translocated and resident sage-grouse within the same study area. Two other studies reported annual survival of translocated sagegrouse. In central Idaho, annual survival of translocated sage-grouse was very low $(36 \%$, 95\% CI 22-50; Musil et al. 1993), but in north central Utah, annual survival $(60.1 \%, 95 \% \mathrm{CI}$ 51.5-68.1; Baxter et al. 2008) was similar to our estimate. It is unclear why survival was so low in the Idaho translocations, because the capture methods, timing of release, and transport methods were similar to the methods we used and those used by Baxter et al. (2008). However, there were differences between the studies in the method of transmitter attach- ment (ponchos vs. necklaces) and transmitter weight ( $25 \mathrm{~g}$ vs. 19-22 g), which may have contributed to the difference in survival. Annual survival of resident adult female sage-grouse in Montana, Wyoming, and Colorado ranged from 54\%-63\% (Zablan 1993, Holloran 2005, Moynahan et al. 2006). Thus, our annual survival estimates of both translocated and resident sage-grouse were within the range for resident birds at many other locations.

Our study provides further evidence that translocation can be an effective method for augmenting small or declining sage-grouse populations. The success of our translocations was likely due to the methods we used to capture and release the grouse, the characteristics of our study area, and an extant population (Reese and Connelly 1997). Our study area is isolated by both natural barriers and large distances $(>60 \mathrm{~km})$ from other known sage-grouse populations, making it less likely that the birds, once released, would attempt to leave the study area. We also released all of the birds near the only known lek in the area as recommended by Reese and Connelly (1997). All but 5 translocated hens were observed near $(<100 \mathrm{~m})$ the lek within 7 days postrelease, supporting the suggestion that translocated females are attracted to leks when released during the breeding season (Emmons and Braun 1984, Dunn and Braun 1985, Gates 1985, Gibson 1992, Reese and Connelly 1997). 
Since the translocation effort started, the number of males observed on the lek at CLWNR has increased from 5 in 2005 to 16 in 2011, suggesting that the population is increasing (Horney 2010). The observation of an increase over such a short period does not necessarily indicate a long-term trend (Fedy and Doherty 2011), but it is encouraging, especially considering that the population declined over the previous decade. If the increase is related to the translocation, it is unclear whether the increase was a direct result of adding individuals to the population, thereby reducing demographic stochasticity (Boyce et al. 2006), or an indirect result of increasing the fitness of individuals in the population via increased genetic heterozygosity and reduced inbreeding (Chapman et al. 2009).

It has been suggested that translocated sage-grouse are more vulnerable to predation after release because of their lack of knowledge of the habitat and hiding cover (Baxter 2003, Baxter et al. 2008, Hagen 2011). Our data showed no evidence for a difference in survival between translocated and resident hens either during the first year after release or during subsequent years. The lack of difference was not an artifact of sample size. Survival of first-year translocated grouse was actually slightly higher than survival of resident and posttranslocated grouse (0.962 \pm 0.009 and $0.953 \pm 0.011$ monthly survival, respectively), although the confidence intervals overlapped broadly. In addition, we observed all translocated hens with nontranslocated grouse within the first year, suggesting that they integrated into the resident population. Our observations are consistent with the suggestion that rapid integration of translocated grouse into a resident population enhances their survival (Baxter 2003, Baxter et al. 2008, Bell 2011).

Our study suggests that survival during the nesting and early brood-rearing period may be lower than survival during the rest of the year, which is consistent with other studies. In Utah, survival of translocated hens during the nesting and early brood-rearing period was lower than survival during the rest of the year (Baxter et al. 2008). It is possible that sagegrouse hens are more vulnerable to predators during the nesting period either because they are easier to capture when incubating or they are less vigilant when foraging. Bunnell (2000) reported red fox (Vulpes vulpes) in Strawberry Valley, Utah, which have been known to kill incubating hens. Our study area has no known confirmed sightings of red fox, but coyotes (Canis latrans) are frequently observed and are a known predator of sage-grouse (Connelly et al. 2000, Schroeder and Baydack 2001).

\section{ACKNOWLEDGMENTS}

We thank the U.S. Fish and Wildlife Service-Klamath Basin National Wildlife Refuges and California Department of Fish and Game for funding this project. We also thank the many members of the Clear Lake Sage-Grouse Working Group, Oregon Department of Fish and Wildlife, Nevada Department of Wildlife, and Hart Mountain National Antelope Refuge for their collaboration and support. A special thanks to J. Beckstrand and D. Mauser for their dedication and support for this project and the many field technicians and volunteers who have made significant field contributions. We also thank 2 anonymous reviewers for constructive comments on earlier drafts of this manuscript.

\section{Literature Cited}

Barbour, M., T. Keeler-Wolf, and A.A. Schoenherr. 2007. Terrestrial vegetation of California. University of California Press, Los Angeles, CA. 754 pp.

BAXTER, R.J. 2003. Greater Sage-Grouse brood and nonreproductive female habitat selection and population dynamics in Strawberry Valley, Utah. Master's thesis, Brigham Young University, Provo, UT.

BaXter, R.J., J.T. Flinders, And D.L. Mitchell. 2008. Survival, movements, and reproduction of translocated Greater Sage Grouse in Strawberry Valley, Utah. Journal of Wildlife Management 72:179-186.

BELL, C.B. 2011. Nest site characteristics and nest success of translocated and resident Greater Sage Grouse at Clear Lake National Wildlife Refuge. Master's thesis, Humboldt State University, Arcata, CA.

Boyce, M.S., C.V. Haridas, C.T. LeE, AND NCEAS STOChastic Demography Source. 2006. Demography in an increasingly variable world. Trends in Ecology and Evolution 21:141-148.

BunnelL, K.D. 2000. Ecological factors limiting sage grouse recovery and expansion in Strawberry Valley, UT. Master's thesis, Brigham Young University, Provo, UT.

Burnham, K.P., And D.R. Anderson. 2002. Model selection and multi-model inference: a practical information-theoretic approach. 2nd edition. Springer-Verlag, New York, NY

Chapman, J.R., S. Nakagawa, D.W. Coltman, J. Slate, AND B.C. Sheldon. 2009. A quantitative review of 
heterozygosity-fitness correlations in animal populations. Molecular Ecology 18:2746-2765.

Clark, W.R., T.R. BOgenschutZ, and D.H. TESSIN. 2008. Sensitivity analysis of a projection model of Ringnecked Pheasants. Journal of Wildlife Management 72:1605-1613.

Connelly, J.W., K.P. Reese, W.L. Wakkinen, M.D. Robertson, and R.A. Fischer. 1994. Sage grouse ecology report. Idaho Department of Fish and Game, Job Completion Report W-160-R-19, Subproject 9, Boise, ID.

Connelly, J.W., M.A. Schroeder, A.R. Sands, And C.E. BRAUN. 2000. Guidelines to manage sage grouse populations and their habitats. Wildlife Society Bulletin 28:967-985.

Crawford, J.A., R.A. Olson, N.E. West, J.C. Mosley, M.A. Schroeder, T.D. Whitson, R.F. Miller, M.A. GREGG, AND C.S. Boyd. 2004. Ecology and management of sage-grouse and sage-grouse habitat. Journal of Range Management 57:2-19.

Crunden, C.W. 1963. Age and sex of sage grouse from wings. Journal of Wildlife Management 27:846-849.

Dahlgren, D.K. 2009. Greater Sage-Grouse ecology, chick survival, and population dynamics, Parker Mountain, Utah. Master's thesis, Utah State University, Logan, UT.

Devers, P.K., D.F. Stauffer, G.W. Norman, D.E. Steffen, D.M. Whitaker, J.D. Sole, T.J. Allen, S.L. Bittner, D.A. Buehler, J.W. EdWards, ET AL. 2009. Ruffed Grouse population ecology in the Appalachian region. Wildlife Monographs 168:1-36.

Dunn, P.O., And C.E. Braun. 1985. Natal dispersal and lek fidelity of sage grouse. Auk 102:621-627.

EMmons, S.R., AND C.E. BRAun. 1984. Lek attendance of male sage grouse. Journal of Wildlife Management 48:1023-1028.

Evans, C. 1986. The relationship of cattle grazing to sage grouse use of meadow habitat on the Sheldon National Wildlife Refuge. Master's thesis, University of Nevada, Reno, NV.

Fedy, B.C., AND K.E. Doherty. 2011. Population cycles are highly correlated over long time series and large spatial scales in two unrelated species: Greater Sage-Grouse and cottontail rabbits. Oecologia 165: 915-924.

GATES, R.J. 1985. Observations of the formation of a sage grouse lek. Wilson Bulletin 97:219-221.

GibSON, R.M. 1992. Lek formation in sage grouse: the effect of female choice on male territory settlement. Animal Behaviour 43:443-450.

Giesen, K.M., T.J. SchoenberG, and C.E. Braun. 1982. Methods for trapping sage grouse in Colorado. Wildlife Society Bulletin 10:224-231.

GregG, M.A., J.A. Crawford, M.S. Drut, and A.K. DELONG. 1994. Vegetational cover and predation of sage grouse nests in Oregon. Journal of Wildlife Management 58:162-166.

Hagen, C.A. 2011. Predation on Greater Sage-Grouse: facts, process, and effects. In: S.T. Knick and J.W. Connelly, editors, Greater Sage-Grouse: ecology and conservation of a landscape species and its habitats. Volume 38, Studies in Avian Biology. University of California Press, Berkeley, CA.

HALL, F.A. 1995. Determining changes in abundance of sage grouse (Centrocercus urophasianus) in California. Unpublished report, dated 1 Aug 1995. California Department of Fish and Game, Sacramento, CA.
Holloran, M.J. 2005. Greater Sage-Grouse (Centrocercus urophasianus) population response to natural gas field development in western Wyoming. Dissertation, University of Wyoming, Laramie, WY.

Horney, M. 2010. Conservation strategy for sage grouse (Centrocercus urophasianus) and sagebrush ecosystems within the Devil's Garden/Clear Lake population management unit. Unpublished Report, 8 April 2010.

Johnson, K.H., And C.E. BRaun. 1999. Viability and conservation of an exploited sage grouse population. Conservation Biology 17:77-84.

Moynahan, B.J., M.S. LindberG, and J.W. Thomas. 2006. Factors contributing to process variance in annual survival of female sage-grouse in Montana. Ecological Applications 16:1529-1538.

Musil, D.D., J.W. Connelly, and K.P. Reese. 1993. Movements, survival, and reproduction of sage grouse translocated into central Idaho. Journal of Wildlife Management 57:85-91.

Oyler-McCance, S.J., S.E. Taylor, and T.W. Quinn. 2005. A multilocus population genetic survey of the Greater Sage-Grouse across their range. Molecular Ecology 14:1293-1310.

Reese, K.P., And J.W. Connelly. 1997. Translocations of sage grouse Centrocercus urophasianus in North America. Wildlife Biology 3:235-241.

Schroeder, M.A., C.L. Aldridge, A.D. ApA, J.R. Bohne, C.E. Braun, S.D. Bunnell, J.W. Connelly, P.A. Deibert, S.C. Gardner, M.A. Hilliard, et al. 2004. Distribution of sage-grouse in North America. Condor 106:363-376.

Schroeder, M.A., and R.K. Baydack. 2001. Predation and the management of prairie grouse. Wildlife Society Bulletin 29:24-32

Schroeder, M.A., J.R. Young, and C.E. Braun. 1999. Sage grouse (Centrocercus urophasianus). No. 425 in A. Poole and F. Gill, editors, The Birds of North America. The Birds of North America, Inc., Philadelphia, PA.

ShuFord, W.D., AND T. GARDALI. 2008. California bird species of special concern: a ranked assessment of species, subspecies, and distinct populations of birds of immediate conservation concern in California. Studies of Western Birds 1. Western Field Ornithologists, Camarillo, CA, and California Department of Fish and Game, Sacramento, CA.

Taylor, R.L., B.L. Walker, D.E. Naugle, and L.S. MILLS. 2012. Managing multiple vital rates to maximize Greater Sage-Grouse population growth. Journal of Wildlife Management 76:336-347.

[USFWS] United States Fish and Wildlife Service. 2010. Twelve-month finding for petitions to list the Greater Sage-Grouse (Centrocercus urophasianus) as threatened or endangered. Federal Register 75: 13909-14014.

WaLLESTAD, R. 1975. Life history and habitat requirements of sage grouse in central Montana. Montana Department of Fish and Game, Helena, MT.

[WrCC] Western Regional Climate Center. 2010. Termo 1 E, California (048873). National Climatic Data Center, Northern California Climate Summaries; [cited 25 October 2010]. Available from: http:/www.wrcc.dri.edu/.

White, G.C., AND K.P. Burnham. 1999. Program MARK: survival estimation from populations of marked animals. Bird Study 46 (Supplement):120-138. 
ZABLAN, M.A. 1993. Evaluation of sage grouse banding program in North Park, Colorado. Master's thesis, Colorado State University, Fort Collins, CO.

Zablan, M.A., C.E. Braun, and G.C. White. 2003. Estimation of Greater Sage-Grouse survival in North
Park, Colorado. Journal of Wildlife Management 67: 144-154.

Received 23 May 2011 Accepted 16 March 2012 